\title{
Major Issues of Post-earthquake Housing Construction during Resettlement
}

\author{
Raju Sarkar $^{1,2}$, Karan Narang ${ }^{3}$ and Sonam Yangdhen ${ }^{4}$ \\ 1. Dept. of Civil Engineering and Architecture, College of Science and Technology, Rinchending P.O. Box 450, Bhutan \\ 2. Department of Civil Engineering, Delhi Technological University, Bawana Road, Delhi 110042, India \\ 3. Bechtel Corporation, Knowledge Park, 244-24, Udyog Vihar, Phase-IV, Gurgaon, Haryana 122015, India \\ 4. Engineering Adaptation and Risk Reduction Division, Department of Engineering Services, Ministry of Works and Human \\ Settlement, Thimphu 11001, Bhutan
}

\begin{abstract}
Natural disasters provide an acute image of how man-made technologies are a cause of conflict when it comes to nature. It is man versus wild in its true means. The nature lets us grow and increase our settlements. We encroach on other animals' territories and it is only when the environment's patience runs out that it retaliates in forms of natural disasters. These disasters affect numerous lives and kill a lot of humans. This is the main reason why we require more stable structures and preventive measures to battle the wrath of the nature. Rescue and search operations are conducted by many different government and private agencies including NGOs. These operations aim at providing the required relief and supplies after the disaster. Injured people need to be treated. People in dangerous zones need to be evacuated. Help is needed in many forms. Out of the many natural disasters, this paper will focus on the occurrence of earthquakes. Severe earthquakes destroy buildings and structures like roads, bridges etc. and wreak havoc in the community. Earthquakes largely damage all human constructions, including houses. This is the reason why a reconstruction program for dwellings and housings is of utmost importance. A home is only secondary to basic needs such as food and water. A well-planned strategy is important when it comes to launching a post-earthquake reconstruction program. The strategy should be reasonable and should consider the best interests of everyone affected; self-help and imported fabrication should play no part in the decision-making procedures. Creating awareness, physically demonstrating options and delivering are the three steps for the success of reconstruction programs. The extent of affected area and the magnitude of earthquakes are variable in nature and it is on these two aspects that the reconstruction strategy is devised. Technical aspects are focused towards the development of the affected areas and conceptual design of surrounding neighborhoods. It also aims at identifying seminars and programs based on easy financing for a new home. Along with these, review processes are conducted for the analysis of new residential needs based on optimizing the use of available land for planning and development. The paper discusses the construction of housing and resettlements as prioritized activities that must be undertaken post an earthquake. Earthquakes physically only destroy structures and buildings but for the people affected, they destroy lives, jobs, companies, sources of food and the sense of safety and traumatize the ones who come out alive.
\end{abstract}

Key words: Post-earthquake reconstruction, resettlement, holistic planning, housing construction.

\section{Introduction}

"We're both in the building business and people have built buildings without pillars, without iron rods in the concrete and with very loose concrete, Youraj Sharma said. He was on the ground floor of a hotel meeting with six friends in the business and hotel just

Corresponding author: Raju Sarkar, Ph.D., professor, research fields: earthquake and environmental geotechnology, soil-structure interaction, vulnerability and risk assessment, disaster management education. fell down on them”. "In an Already Troubled Nepal, a Picture of Despair Emerges”, The New York Times, 26th April, 2015, p. 1.

"Entire generations are gone. My grandfather, my mother, all her sisters, my brother, everyone is gone. There were 40 people in the house then, only nine have survived. We were conducting the puja to make the gods happy, they instead gave us their wrath, says Nishchal Guruwacharya from Chamati area of Naya Bazar in Kathmandu.” "Nepal Earthquake Shakes 
Faith of Some, Turns Others into Believers Overnight”, Times of India, 29th April, 2015, p. 1.

-After Nepal Earthquake, 25th April, 2015.

Earthquakes occur due to the instability in the Earth's crust. Whenever a tectonic plate shifts or moves even a slight inch, it causes catastrophic changes to human lives. An abrupt release of the built up strain in the Earth's surface causes this movement of tectonic plates. Though researchers are trying to predict earthquakes applying various conventional technologies, but the findings are inconclusive till date. After hurricanes, tornadoes, pre-fabricated houses and mobile homes that are a low cost form of housing are vastly impacted [1]. Old constructions that are built in the flood plains without required elevations prove to be less stable than any newly constructed structures thereby, leading to disproportionate damage during earthquakes as it is generally in a densely populated section of town. Repairing, rebuilding and rehabilitation in such areas often result in higher expense which in turn is unaffordable for people with lower income [2]. Table 1 shows the effect of natural disasters on the surface of the earth, on infrastructure and on agriculture [3]. From the table it is concluded that effects on infrastructure are maximum in case of earthquake.

Effective management of destruction post an earthquake is critically important and is in direct proportion to the overall success of recovery effort. Identification of dwellings that can survive without engineering evaluations or area vulnerability assessments for these areas has been effectively strategized. This maneuvering is very convenient for assuaging the needs of temporary housing and providing substantial evidence of progress whilst other rebuilding issues are deliberated upon. Local planners have cited that design details become important to recovery efforts after an earthquake [4]. Any rebuilding project requires a blend of new buildings with old ones. Generating public consensus on major urban design issues is crucial so that reconstruction options are not lost. Calling experts from unaffected regions to develop plans does not garner support from local affected population as it devalues the need for victims of the same disaster to come together and solve the community's problems in a cooperative manner [5].

\section{Rebuilding Procedures Are Long Drawn Processes}

In comparison to constructing newer structures, rebuilding damaged property post an earthquake requires vast financial aid, emotional support as well as technical expertise as it is more difficult and time-consuming. Sustainable development strategies call for a proper decision-making time frame. For execution of retrofitting and new construction of houses during post-earthquake reconstruction phase, available codal provisions must follow. There are no shortcuts available for relocation and/or elevation of residences, and upgradation of critical infrastructure. Citizens should be provided with appropriate waiver in costs as well as their customary and legitimate requirements must be met. This includes environmental scrutinisation and appropriate cost benefit analysis [6]. Policy adjustments for the ablation of the perils are available during recovery period. This delays any upcoming rebuilding opportunities.

\section{Failures Observed during Post-earthquake Resettlement}

Causes of resettlement failure: Poor resettlement choices and decisions are the major cause of failure. In most cases, the chosen sites for resettlement after an earthquake are to cater the overall development of the general population. Generally for resettlement purposes, the land designated is the one that can be easily acquired, particularly when it is government-owned. Resettlement sites thus chosen do not have access to vital resources such as water, labour, and other utilities and commodity markets. Other major causes of failure are factors such 
Table 1 Effect of natural disasters on the surface of the earth, on infrastructure and on agriculture (After Cuny [10]).

\begin{tabular}{|c|c|c|c|}
\hline Type of disaster & Effects on the earth surface & Effects on infrastructure & Effects on agriculture \\
\hline Earthquakes & \begin{tabular}{|l|} 
Tremors and cracks \\
Landslides liquefaction \\
Underground settling and \\
Rock falls \\
Avalanches and mudslides \\
Changes in underground water \\
courses
\end{tabular} & \begin{tabular}{|l|} 
Damage to constructions (productive, \\
e.g. factories, public, social, housing, \\
and cultural heritage) \\
Diverse damage in roads, bridges, \\
dikes and channels \\
Broken ducts, pipes, posts and wires \\
Burial and undermining of dams, \\
silting of rivers causing local floods \\
Sinking of structures and buildings \\
Deterioration of underground \\
constructions
\end{tabular} & $\begin{array}{l}\text { Minimal } \\
\text { Localized losses in areas affected by } \\
\text { landslides, avalanches or liquefaction } \\
\text { Temporary loss of irrigation systems } \\
\text { Localized losses in plants and plant cover } \\
\text { and forests }\end{array}$ \\
\hline $\begin{array}{l}\text { Hurricanes, } \\
\text { typhoons and } \\
\text { cyclones }\end{array}$ & $\begin{array}{l}\text { Strong winds, both steady and } \\
\text { gusts floods (due to rain and } \\
\text { swollen and burst rivers) }\end{array}$ & $\begin{array}{l}\text { Damage to buildings } \\
\text { Impact-damaged, broken and fallen } \\
\text { distribution lines, especially overhead } \\
\text { Damage to bridges and roads due to } \\
\text { landslides, avalanches and torrential } \\
\text { mudslides }\end{array}$ & $\begin{array}{l}\text { Loss of plant cover, fallen trees, crop } \\
\text { damage, especially wind damage to grass } \\
\text { species } \\
\text { Erosion affects root and tuber crops } \\
\text { Changes in natural and man-made drainage } \\
\text { systems } \\
\text { Sedimentation, salinization, contamination } \\
\text { and erosion of soils }\end{array}$ \\
\hline Drought & $\begin{array}{l}\text { Drying and cracking of the } \\
\text { earth and loss of plant layer } \\
\text { Exposure to wind erosion } \\
\text { Desertification }\end{array}$ & Does not cause major losses & $\begin{array}{l}\text { Loss of crop and plant cover } \\
\text { Erosion and damage to forests } \\
\text { Depositing of sand and infertile earth } \\
\text { Changes to crop types and cycles } \\
\text { Growth of arid climate, drought-resistant } \\
\text { vegetation, such as thorn bushes and } \\
\text { cactuses }\end{array}$ \\
\hline Floods & $\begin{array}{l}\text { Erosion } \\
\text { Water-logging and } \\
\text { destabilization of soils, } \\
\text { landslides } \\
\text { Sedimentation }\end{array}$ & $\begin{array}{l}\text { Loosening of foundations and piles of } \\
\text { buildings Burial and slippage of } \\
\text { constructions and infrastructure works } \\
\text { Blockage and silting of channels and } \\
\text { drains }\end{array}$ & $\begin{array}{l}\text { Destroys crops, alters crop types and } \\
\text { growing cycles } \\
\text { Localized damage in land, fields and woods } \\
\text { Increased humidity improves quality of } \\
\text { some land and makes it productive (albeit } \\
\text { temporarily) }\end{array}$ \\
\hline $\begin{array}{l}\text { Seaquakes or } \\
\text { tsunamis }\end{array}$ & \begin{tabular}{|l|} 
Floods \\
Salinization and sedimentation \\
in coastal strips \\
Contaminate water and water \\
table
\end{tabular} & $\begin{array}{l}\text { Destroy or damage buildings, bridges, } \\
\text { roads, irrigation and drainage systems }\end{array}$ & $\begin{array}{l}\text { Localized damage in crops } \\
\text { Destruction of coastal plantations } \\
\text { Changes in reproductive cycles of coastal } \\
\text { fauna and damage to fishing }\end{array}$ \\
\hline $\begin{array}{l}\text { Volcanic } \\
\text { eruptions }\end{array}$ & \begin{tabular}{|l|} 
Fires, loss of plant cover \\
Depositing of incandescent \\
material and lava \\
Depositing of ash \\
Deterioration of soils due to \\
settling of airborne chemicals \\
Landslides, avalanches and \\
torrential mudslides \\
Liquefaction \\
Melt-waters and avalanches \\
\end{tabular} & \begin{tabular}{|l|} 
Destroys buildings and all types of \\
infrastructure \\
Collapsed roofs due to ash deposits \\
Burial of buildings \\
Fires \\
Affects channels, bridges and \\
overhead and underground conduction \\
and transmission lines
\end{tabular} & $\begin{array}{l}\text { Extensive defoliation } \\
\text { Damage to plant cover and forests } \\
\text { Fires in areas near eruption } \\
\text { Burial of crops, damage to productive land } \\
\text { due to silting, contamination and landslides } \\
\text { Fires in plantations } \\
\text { Ash deposits increase fertility of damaged } \\
\text { soils }\end{array}$ \\
\hline
\end{tabular}

as distance from one's kin or from the old villages that are targeted for resettlement.

Housing design and construction methods: Design and methods of construction of resettlement projects after an Earthquake are mostly held responsible for the failures that occur. Faults that occur during the construction of housing units are responsible for creating difficult and non-viable circumstances for the occupants especially when changing seasons create different weather conditions. In most cases, the same building techniques are used and the construction planners fail to realize that implementation of these older techniques was the primary reason why the buildings were unsafe and prone to damage in the first 
place. The designing aspect of the new buildings is also not proper at times and the house is not suited to serviceability of numerous domestic activities. Reconstruction projects fail mostly because the people who would occupy the houses are rarely consulted. This creates a communication gap and the planners fail to cater to the needs of the people.

\section{Holistic Planning after the Earthquake}

During the post-earthquake reconstruction, people's participation is vital. The planners must consult the people who would be the future residents of the resettlement project buildings that are constructed. Master planning must consider both the needs of people as well as environmental needs. The planning should be such that it encourages cooperation between people and environment rather than competition. "Sustainable development" is the modified name of "holistic planning" these days. It is important to ensure that the project is environmentally relevant, causes less damage to the environment and causes minimal lesser consumption of non-renewable energy resources. "Think globally and act locally" should be the motto.

\section{Building Materials and Sustainability}

During post-earthquake restoration, buildings and the equipments must meet the needs of the affected victims' demand for energy and material resources. To make indoor environments comfortable, accessible and alluring, sustainable designs and construction practices should be opted for. These techniques can help in the reduction of flow of energy, waste generated and materials used. Buildings that are energy efficient, can significantly add to the benefits of sustainable development by reducing the amount of energy used and thus reducing the environmental impact. For long term sustainability, some aspects are taken into consideration, such as the resettlement should be pollution-free, efficient when it comes to resources, holistic in development and health concerns should not arise. Building materials that are available locally are the most preferred. These are made from renewable resources, easily handled by the local skilled labour and use little energy to be produced, transported and installed. Following the mentioned standards, wood seemed to be the best choice of material. Sustainable building materials have:

- Durability—to increase the life of the building;

- Recyclability - they should have the potential to be used again and again;

- Efficiency—energy loss should be minimal;

- Ecological sustainability—they should be locally available and renewable;

- Non-toxicity - the air should not be toxic inside the constructed houses.

\section{Beyond Codes to Community Design}

It's not just important to consult the residents of the affected community; it is also very important to look at the community as a whole instead of treating them as individual citizens. The same holds for all the construction features that are being reconstructed. It's not just the buildings but the park, streets and other infrastructures that are considered basic amenities of a neighborhood. The process is thus very complex as compared to constructing a designated number of buildings.

Implementing disaster resistant community design will provide long-term solutions for the localities. Disaster resistant community designs not only include codal solutions but further engirdle site and neighborhood sign advances that include mole intricate interactions amongst natural hazards and their built/erected environment. For the mitigation of hazards from the development phase itself, disaster-resistant community design methods are required to be implemented. A more refined, multidisciplinary approach to hazard minimization is being engaged in by many city governments. Planning departments coordinate with fire-fighters, police, public work department, transportation in charges and 
other city staff to diminish the level of risk.

\section{Criterion to Deem an Earthquake Resettlement Project Successful}

Proper planning is necessary when the long-term development of a community and its people is considered. The resettlement project that is carried out has multiple facets and provides opportunities to reconstruct systems related to production as well as human settlements. The main aim of this whole project is to help people return to their livelihood in very little time so that they get opportunities to become independent economically and support their family on their own. The project is successful when the dependency of people on settlement agencies ends and they become self-sustained. This implies that the resettlement project has more to it than just making more concrete structures. When the general population also gets involved in the decision making process and implementing the project milestones, the resettlement project takes a socio-cultural turn and the chances of its success increase greatly. Along with this, if the victims are offered employment within the project itself, it optimizes the expenditure and motivation. It is imperative that new employment opportunities are created close to the resettlement area to make the lives of people easy by letting them cope with the after effects of the disaster initially.

\section{Post-earthquake Housing-Appropriate Repair, Restoration and Strengthening Concepts}

The evidence of destruction and damage caused during a recent earthquake raises an urgent need to improve the ability of an existing building to withstand seismic forces. The evidence can also be seen when analogous buildings situated in other areas are observed. These buildings have suffered damage and through this observation, the weaknesses in construction techniques can be identified. In most cases, if residents are asked to spend some money on the enhancement of the building to make it safer and to protect it from damage due to seismic forces, they mostly feel reluctant to spend more.

Only when a building survives an earthquake can it be said that the building is earthquake resistant. There is a need to strengthen the weaker buildings when it is diagnosed that they are not stable enough to withstand the seismic forces of an earthquake. We can identify weaker buildings by their visible damage and with comparisons to similar buildings in the surrounding area.

Repair and strengthening procedures would largely depend on the materials used in construction and the structural scheme. The technology used in the process depends on the funds assigned to the project.

The underlying concepts of the three operations are offered by the Indian Society of Earthquake Technology [7].

\subsection{Repairs}

Repairing not just refers to filling the gaps and cracks and only hiding the faults by plaster and concrete. The main purpose of repairing a building makes it functional so that all the facilities in the building start working without any glitches. The main objective is to restore the original shape of any architecture so that its beauty is retained. Repairs do not increase the strength of a building but restore only to what it originally was.

These repairs mostly cater only to the eye improving the aesthetic aspect of the structure. They do not increase the strength and stability of the load bearing elements of the building. Since these changes disguise the actual problems, the restored building is prone to undergoing even more damage in the next earthquake as it has become very weak in strength but looks strong.

\subsection{Restoration}

Restoration is done to improve the strength of the building after damage has occurred. This step should 
mandatorily keep in mind that the strength of the building needs to be increased instead of just concentrating on making the interiors and exteriors aesthetics of the building look good. It is the key for strengthening of load bearing elements and satisfying the serviceability criteria of the structure. This can be done either by replacing the older elements by newer ones or strengthening the damaged parts through retrofitting techniques. It should also be made sure that the newly restored parts are in tandem with the older design and that the overall stability of the building is improved. To avoid wastage, structural repairs are generally carried out before or in situ with architectural repairs so that the complete planning of work is not affected.

\subsection{Strengthening of Existing Buildings}

Original structural inadequacies, observed degradation and creeping effect in material due to time, structural alterations like the introduction of new openings, and parts carried out during use over the years are some of the factors due to which seismic behavior of existing (old) buildings is affected. Existing buildings cannot be replaced with newer, more resistant buildings because of their historical importance and economical considerations. Replacing all buildings in a given area leads to the destruction of heritage and social links. Seismic strengthening of these buildings will help preserve its socio-economic value.

Strengthening is an improvement over the original strength where the evaluation of the building indicates that the strength available before the damage was insufficient and restoration will not be adequate in future quakes [8]. The extent of the modifications must be determined by the general principles and design methods and should not be limited to increasing the strength of the members that have been damaged, but should consider overall behavior of the structure [9].

\section{Conclusion}

Earthquakes often make specialists re-think the designing of structures and the formation of post-earthquake resettlement plans. They make experts conduct comprehensive surveys to get to the root of every problem to ensure that the next time a disaster strikes, the damage caused would be even lesser. They identify vulnerabilities and formulate plans to overcome them. Support for hazard mitigation is the strongest post-disaster; with appropriate construction, repair, and land-use standards, the level of risk posed towards a community can be substantially reduced.

With the emergence of multiple new studies on the topic, local resources and talents are increasingly being used in present day relief and reconstruction measures. As we know newly constructed houses not only provide shelter for the affected people just after the earthquake but they also provide people with permanent shelter. Further, there has been a growing feeling amongst the rural people that the old bamboo-thatch or leaf houses may be constructed with newer materials of RCC, precast-components etc., using better engineering information and thereby, achieving more durability as well as extra living comfort in the process [10]. Based on the mentioned innovative concept, locally made concrete blocks, wooden frames, and tiles are most useful because by this new establishment of many small-scale enterprises grows up leads to creation of local manpower as well.

"Well-built house" is not the only factor in which successful resettlement of a community depends. The reconstruction after the earthquake does not mean the construction of houses alone, but other necessary requirements viz. water, electricity, sewage treatment facility, security, education, employment, greenery, and socio-communal living, should also be present in order to bridge the gap between external aid and sustainable development.

\section{References}

[1] Delaney, P. L., and Shrader, E. 2000. "Gender and Post-disaster Reconstruction: The Case of Hurricane Mitch in Honduras and Nicaragua." Decision Review Draft LCSPG/LAC Gender Team, the World Bank. 
[2] ECLAC and IDB. 2000. "A Matter of Development: How to Reduce Vulnerability in the Face of Natural Disasters." Seminar on Confronting Natural Disasters: A Matter of Development, New Orleans.

[3] Cuny, F. C. 1983. Disasters and Prevention. New York: Oxford University Press.

[4] Petterson, J. 1999. "A Review of the Literature and Programs on Local Recovery from Disaster.” Natural Hazards Research Working Paper, Federal Emergency Management Agency.

[5] Ranganath, P. 2000. "Mitigation and the Consequences of International Aid in Postdisaster Reconstruction.” Natural Hazards Research Working Paper, McGill University.

[6] National Information Centre of Earthquake Engineering 2007. Repair, Restoration and Strengthening of Buildings. Handbook, Kanpur: Indian Institute of Technology.
[7] Indian Society of Earthquake Technology. 2001. “A Manual of Earthquake Resistant Non-engineered Construction.” Roorkee, India.

[8] Rafi, S. 2000. "Disaster Preparation and Post-disaster Reconstruction in Burgeoning Cities of Developing Countries." Inter-American Committee on Natural Disaster Reduction (IACNDR), Working Group on Finance, First Report, Washington State University.

[9] Langenbach, R. 1989. "Bricks, Mortar, and Earthquakes: Historic Preservation vs. Earthquake Safety.” Aptabulletin, the Journal of the Association for Preservation Technology, Volume XXI, No. 3 and 4.

[10] Sarkar, R. 1997. "The Concept of Eco-development for Rural Housing in North-East India." In Proc. of International Conference on Civil Engineering for Sustainable Development, University of Roorkee. 